УДК 378:373.5.091.12.011.3- 051:811.111

\title{
ПРИНЦИПИ, ВИДИ, ФОРМИ КОНТРОЛЮ Й ВЗАЕМОКОНТРОЛЮ СФОРМОВАНОСТІ В МАЙБУТНІХ УЧИТЕЛІВ КОМПЕТЕНТНОСТІ В АНГЛІЙСЬКОМУ МОНОЛОГІЧНОМУ МОВЛЕННІ
}

\author{
Стельмах Д. О. \\ distelmah@gmail.com \\ Київський національний лінгвістичний університет \\ Національний університет "Чернігівський колегіум" імені Т.Г. Шевченка \\ Дата надходження 30.04.2018. Рекомендовано до друку 28.05.2018.
}

\begin{abstract}
Анотація. В статті розглянуто основні дидактичні й методичні принципи контролю і взаємоконтролю сформованості в майбутніх учителів компетентності в монологічному мовленні: систематичності, об'єктивності, диференційованості, репрезентативності, ясності й чіткості формулювання завдань; комунікативності, автентичності, професійної спрямованості, розвитку автономності студента. Проаналізовано види й форми контролю і взаємоконтролю, які доцільно використовувати для перевірки сформованості в майбутніх учителів англійської мови компетентності в монологічному мовленні в умовах закладу вищої освіти.
\end{abstract}

Ключові слова: контроль, взаємоконтроль, компетентність у монологічному мовленні, майбутні вчителі англійської мови.

Стельмах Д. А. Киевский национальный лингвистический университет, Национальный университет “Черниговский коллегиум” имени Т. Г. Шевченко

Принципы, виды и формы контроля и взаимоконтроля уровня сформированности у будущих учителей компетентности в англоязычной монологической речи

Аннотация. В статье рассмотрены основные дидактические и методические принципы контроля и взаимоконтроля сформированности у будущих учителей компетентности в монологической речи: систематичности, объективности, дифференцированности, репрезентативности, ясности и четкости формулировки заданий; коммуникативности, аутентичности, профессиональной направленности, развития автономности студента. Анализируются виды и формы контроля и взаимоконтроля, которые целесообразно использовать для проверки сформированности у будущих учителей английского языка компетентности в монологической речи в условиях вуза.

Ключевые слова: контроль, взаимоконтроль, компетентность в монологической речи, будущие учителя английского языка.

Stelmakh D. Kyiv National Linguistic University, National University "Chernihiv Collegium" named after T. G. Shevchenko

Principles, types and forms of control and self control of the development of English monologue speech competence of prospective teachers

Abstract. Introduction. The article focuses on the problem of control and self-control of oral speech competence of the prospective teachers, particularly monologue speech. Purpose. To determine basic didactic and methodological principles and to specify the types and forms of control and selfcontrol of the oral monologue competence of the pre-service teachers. Methods. Reviewing the studies on pedagogical and methodical problems of the researches with the view to analyzing principles, types, forms of control and self-control effective in oral monologue speech of the prospective teachers. Results. This paper represented main didactic and methodological principles such as: systematicness, objectivity, differentiation, representativeness, clarity and precision of tasks formation; communicativeness, authenticity, professional orientation, development of the students' independence; analyzed the types and forms of control and selfcontrol of the pre-service teachers' monologue speech competence. Conclusion. To sum up, it has been proved that effective control and selfcontrol of the oral monologue speech competence of the prospective teachers depend on the following of the key didactic and methodological principles and it is realized in variety of types and forms the role of which has been explained in the teaching process. Key words: control, self-control, monologue speech competence, prospective English teachers. 
Постановка проблеми. Основним завданням сучасних мовних і педагогічних закладів вищої освіти в Україні є підготовка висококваліфікованих учителів іноземних мов (IM), здатних здійснювати інтеграцію в міжнародний освітній і науковий простір. Потреба в підготовці фахівців такого рівня вимагає не лише сучасних методів навчання, а й контролю сформованості у майбутніх учителів різних видів компетентностей. Контроль дає можливість викладачеві відстежувати й коригувати навчальну діяльність, а також мотивувати студентів до оволодіння IM.

Одним 3 важливих показників готовності вчителів до міжкультурного спілкування $\epsilon$ сформованість компетентності в монологічному мовленні (КМM), адже саме цей вид мовленнєвої діяльності дає змогу готувати публічні виступи й презентації на міжнародних конференціях, семінарах, вебінарах, а також в аудиторії перед студентами й колегами. Отже, виникає необхідність створення ефективної методики контролю саме цього виду іншомовної комунікативної компетентності.

Аналіз останніх досліджень і публікацій. Дослідження контролю усномовленнєвих умінь перебуває в центрі уваги багатьох науковців. Так, І. П. Задорожна висвітлила питання контролю говоріння в самостійній роботі майбутніх учителів; М. В. Мітіна, О. О. Молокович, О. О. Українська, І. А. Цатурова та С. Р. Балуян вивчали методику тестування усної комунікації; О. С. Парнюгін досліджував контроль усного мовленнєвого спілкування студентів молодших курсів навчання; В. В. Черниш запропонувала завдання для контролю професійно орієнтованого мовлення майбутніх учителів. Незважаючи на численні дослідження, окремої розробки потребує методика контролю й взаємоконтролю рівня сформованості в майбутніх учителів КММ та іiї базові категорії. У нашій попередній публікації ми визначили цілі й функції контролю й взаємоконтролю вищезгаданої компетентності (Стельмах, 2018), проте ефективність будьякої, зокрема й контролюючої діяльності залежить від урахування закономірностей цього процесу, які знаходять своє відображення в принципах, а також від науково обгрунтованого використання різних видів і форм контролю і взаємоконтролю.

Отже, метою статті $є$ виділення й опис принципів, видів, форм контролю і взаємоконтролю сформованості в майбутніх учителів компетентності в англійському монологічному мовленні.

Основні результати дослідження. Принципи навчання у сучасній методиці трактуються як “вихідні положення, які в своїй сукупності визначають вимоги до навчального процесу в цілому і його складників (цілей, завдань, методів, засобів, організаційних форм) зокрема” (Бігич та ін., 2013). Відповідно принципи контролю й взаємоконтролю рівня сформованості КММ відображають основні вимоги до процесу контролю цієї компетентності. Загальноприйнятим у навчанні IM є також поділ принципів на дидактичні й методичні, що, як свідчать дослідження, простежується й у процесі проведення контрольних заходів. Так, серед дидактичних принципів найважливішими для контролю й взаємоконтролю рівня сформованості КММ є систематичність, об'єктивність, диференційованість, репрезентативність (Бігич та ін., 2013; Молокович, 2001; Москалюк, 2010; Шатилов, 1986). Розглянемо кожен 3 них детальніше.

Систематичність контролю й взаємоконтролю, слідом за А. В. Будко, розуміємо, як постійну необхідність викладача одержувати інформацію про рівень засвоєння знань, навичок і вмінь на кожному етапі формування КММ (Будко, 2013). Систематичність передбачає регулярність проведення контрольних заходів, а також “системне надання студентам інформації про результати їхньої праці” (Олендр, 2015).

Об 'єктивність контролю й взаємоконтролю забезпечується шляхом виділення кількісних і якісних критеріїв оцінювання сформованості КММ, доведення їх до відома студентів та, як зазначає Т.А. Кладкова, “суворе їх дотримання” (Кладкова, 2013).

Принцип диферениійованості контролю й взаємоконтролю реалізується шляхом урахування рівня й індивідуально-психологічних особливостей кожного студента, а також шляхом добору методів і форм контролю й взаємоконтролю, доцільних для різних функціональних типів монологів. 
Репрезентативність контролю й взаємоконтролю вимагає перевірки й оцінювання сформованості всіх складників КММ.

Принцип ясності $i$ чіткості формулювання контрольних завдань (доступності) полягає в лаконічному й доступному оформленні контрольних завдань, оскільки успіх їх виконання залежить і від цього фактора. Зокрема завдання для контролю й взаємоконтролю ММ часто вимагають створення комунікативної ситуації й опису ролей, які теж прописуються в настанові.

3-поміж методичних принципів контролю науковці зазвичай виділяють принципи комунікативності й автентичності (Молокович, 2001; Москалюк, 2010), які, на нашу думку, для контролю й взаємоконтролю ММ необхідно доповнити принципами професійної спрямованості й розвитку автономності студентів.

Принцип комунікативності контролю й взаємоконтролю вимагає укладання завдань для перевірки рівня сформованості КММ так, щоб вони моделювали реальні ситуації іншомовного спілкування, містили мотив для створення монологічного висловлювання (Українська, 2009).

Принцип автентичності полягає $y$ використанні автентичних матеріалів у контрольних завданнях.

Професійна спрямованість контролю й взаємоконтролю $є$ вагомою, тому що як контрольні, так і навчальні завдання мають містити ситуації професійного спілкування й перевіряти професійно орієнтоване ММ майбутніх учителів.

Принцип розвитку автономності студентів у контролі КММ реалізується через взаємоконтроль, який привчає студентів відповідально ставитись до процесу оцінювання своїх одногрупників, мимовільно залучає їх до вивчення й розуміння, а можливо й розроблення критеріїв сформованості вмінь ММ і $є$ перехідним етапом до самооцінювання й самокорекції.

Урахування вищезазначених дидактичних і методичних принципів забезпечує ефективне функціонування різних видів контролю й взаємоконтролю рівня сформованості КММ. Традиційно в методиці виділяються такі види контролю: попередній, поточний, рубіжний (тематичний), підсумковий (Бігич та ін., 2013; Вітвицька, 2006; Конишева, 2004). Усі вони реалізуються під час контролю рівня сформованості КММ, проте не всі підлягають взаємоконтролю. Зупинимось на них докладніше.

Попередній контроль дає змогу визначити вихідний рівень володіння ММ або володіння конкретним функціональним типом монологу. Цей вид контролю використовується на початку навчального року, семестру чи нової теми. Здобуті результати допомагають ефективніше планувати формування КММ, з'ясувати, на яких функціональних типах монологу слід зупинитись детальніше, які опори треба надавати і яким студентам. Попередній контроль можна проводити у формі взаємоконтролю, але лише за умов, коли студенти ознайомлені з таким способом контролю, вже неодноразово використовували його й готові тактовно й об'єктивно оцінити ММ своїх одногрупників за чітко визначеними критеріями.

Поточний контроль дає можливість викладачеві швидко й без відриву від навчання виявити, наскільки успішним є формування КММ у межах певної теми на певному етапі та, в разі потреби, скоригувати кількість вправ і часу й прийоми, необхідні для формування того чи іншого компонента КММ. Крім того, поточний контроль привчає студентів до систематичної праці над удосконаленням умінь ММ, вказує, яким мовленнєвим навичкам / вмінням потрібно приділити більше уваги, готує до рубіжного й підсумкового контролю. Поточний контроль доцільно поєднувати із взаємоконтролем, адже саме під час практичних занять вік допомагає зберегти цінний час, привчити студентів до використання такого способу контролю, ознайомити їх з критеріями оцінювання КММ, мотивувати їх.

Рубіжний (тематичний) контроль проводиться по закінченні опрацювання теми (або кількох тем) і має на меті перевірку й оцінку рівня сформованості КММ у межах теми, але в нових 
комунікативних ситуаціях. Рубіжний контроль відрізняється від поточного тим, що перевіряє не компонент КММ (наприклад сформованість лексичних навичок ММ), а компетентність у цілому.

Підсумковий контроль має місце в кінці семестру / навчального року й перевіряє рівень сформованості КММ разом з іншими видами мовленнєвої діяльності. Рубіжний і підсумковий контроль, на нашу думку, варто проводити саме викладачеві.

Різні види й об'єкти контролю й взаємоконтролю визначають форму перевірки мовленнєвих компетентностей. 3-поміж таких форм виділяють: 1) індивідуальні чи фронтальні, групові, парні; 2) усні чи письмові; 3) одномовні чи двомовні (Бігич та ін., 2013; Конишева, 2004; Шатилов, 1989). Очевидно, що перевірку компетентності в ММ під час попереднього контролю логічно здійснювати в усній індивідуальній одномовній формі, або, якщо це взаємоконтроль, - в усній парній одномовній формі. Поточний контроль і взаємоконтроль уможливлюють використання усних індивідуальної, парної чи групової одномовних форм, в той час як для рубіжного чи підсумкового контролю краще застосовувати лише усну індивідуальну форму, щоб мати змогу комплексно оцінити рівень сформованості КММ у кожного студента.

Висновки і перспективи подалыших розвідок. Створення ефективної методики контролю й взаємоконтролю рівня сформованості у майбутніх учителів КММ залежить від урахування дидактичних (систематичності, об'єктивності, диференційованості, репрезентативності, ясності й чіткості формулювання завдань) і методичних (комунікативності, автентичності, професійної спрямованості, розвитку автономності студента) принципів. Контроль ММ реалізується в усіх його видах - попередньому, поточному, рубіжному й підсумковому, в той час як взаємлоконтроль краще застосовувати для попередньої / поточної перевірки КММ. Основними формами контролю й взаємоконтролю для цього виду мовленнєвої діяльності є усні індивідуальні, парні чи групові. Перспективу подальшого дослідження вбачаємо у виділенні об'єктів контролю й взаємоконтролю рівня сформованості у майбутніх учителів КММ і розробленні критеріїв їх оцінювання.

\section{ЛІТЕРАТУРА}

Бігич, О. Б., Бориско, Н. Ф., Борецька, Г. Е., ... Ніколаєва, С. Ю. (Ред.). (2013). Методика навчання іноземних мов і культур: теорія і практика. Київ: Ленвіт.

Будко, А. В. (2013). Сутність понять “контроль” та “оцінювання” навчально-пізнавальної діяльності. Вісник ЛНУ імені Тараса Шевченка, 15, 57-62.

Вітвицька, С. С. (2006). Основи педагогіки вищої иколи [підручник за модульно-рейтинговою системою навчання для студентів магістратури]. Київ: Центр навчальної літератури.

Кладкова, Т. А. (2013). Контроль і оцінювання у процесі формування іншомовної комунікативної компетентності студентів немовних спеціальностей. Вісник Чернігівського національного педагогічного університету, 112, 141-145.

Конышева, А. В. (2004). Контроль результатов обучения иностранному языку. Санкт-Петербург: KAPO.

Молокович, О. (2001). Тестовий контроль рівня володіння говорінням англійською мовою як другою іноземною у студентів 2-го курсу мовного факультету. (Кандидатська дисертація). Київський національний лінгвістичний університет, Київ, Україна.

Москалюк, Л. (2010). Реалізація мотиваційного компонента контролю англомовної лексичної компетениії молодиих школярів. (Кандидатська дисертація). Київський національний лінгвістичний університет, Київ, Україна.

Олендр, Т.М. (2015). Деякі проблеми використання інноваційних технологій контролю і оцінювання знань студентів на заняттях з іноземних мов за професійним спрямуванням. Педагогічні науки: теорія, історія, інновачійні технологї, 4, 355-364. 
Пассов, Е. И. (1989). Основы коммуникативной методики обучения иноязычному общению. Москва: Русский язык.

Стельмах, Д. (2018) Цілі та функції контролю та взаємоконтролю рівня сформованості вмінь англійського монологічного мовлення майбутніх учителів. Полілог мов $i$ культур: освітній i культурологічний аспекти. Матеріали Всеукраїнської науково-практичної конференції молодих науковців, 27 березня 2018 р. (сс. 48-50). Чернігів: РВВ ЧНПУ імені Т. Г. Шевченка.

Українська, О. (2009). Методика тестування рівня сформованості мовленсвої компетениї майбутніх викладачів у говорінні франиузькою мовою. (Кандидатська дисертація). Київський національний лінгвістичний університет, Київ, Україна.

Черниш, В. (2015). Теоретико-методичні засади формування у майбутніх вчителів професійноорієнтованої англомовної компетениії в говорінні. (Докторська дисертація). Київський національний лінгвістичний університет, Київ, Україна.

Шатилов, С. Ф. (1986). Методика обучения немеикому языку в средней иколе. Москва: Просвещение.

\section{REFERENCES}

Bigych, O. B., Borysko, N. F., Borets'ka, G. E., ... Nikolajeva, S. Yu. (Red.). (2013). Metodyka navchannya inozemnykh mov i kul'tur: teoriya i praktyka. Kyjiv: Lenvit.

Budko, A. V. (2013). Sutnist' ponyat' "kontrol"” ta "otsinyuvannya" navchal'no-piznaval'noji diyal'nosti. Visnyk LNU imeni Tarasa Shevchenka, 15, 57-62.

Vitvyts'ka, S. S. (2006). Osnovy pedagogiky vyshchoji shkoly: pidruchnyk za modul'no-rejtyngovoyu systemoyu navchannya dlya studentiv magistratury. Kyjiv: Tsentr navchal'noJi literatury.

Kladkova, T.A. (2013). Kontrol' i otsinyuvannya u protsesi formuvannya inshomovnoJi komunikatyvnoji kompetentnosti studentiv nemovnykh spetsial'nostej. Visnyk Chernigivs'kogo natsional'nogo pedagogichnogo universytetu, 112, 141-145.

Konysheva, A. V. (2004). Kontrol' rezul'tatov obuchenyya inostrannomu yazyku. Sankt-Peterburg: KARO.

Molokovych, O. (2001). Testovyj kontrol' rivnya volodinnya govorinnyam anglijs'koyu movoyu yak drugoyu inozemnoyu u studentiv 2 kursu movnogo fakul'tetu. (Kandydats'ka dysertatsiia). Kyivs'kyj natsional'nyj linhvistychnyj universytet, Kyiv, Ukraina.

Moskalyuk, L. (2010). Realizatsiya motyvatsijnogo komponenta kontrolyu anglomovnoji leksychnoji kompetentsiji molodshykh shkolyariv. (Kandydats'ka dysertatsiia). Kyivs'kyj natsional'nyj linhvistychnyj universytet, Kyiv, Ukraina.

Olendr, T. M. (2015). Deyaki problemy vykorystannya innovatsijnykh tekhnologij kontrolyu i otsinyuvannya znan' studentiv na zanyattyakh z inozemnykh mov za profesijnym spryamuvannyam. Pedagogichni nauky: teoriya, istoriya, innovatsijni tekhnologiJi, 4, 355-364.

Passov, E. Y. (1989). Osnovy kommunykatyvnoj metodyky obucheniya ynoyazychnomu obshcheniyu. Moskva: Russkyj yazyk.

Stel'makh, D. (2018) Tsili ta funktsii kontroliu ta vzaiemokontroliu rivnia sformovanosti vmin' anhlijs'koho monolohichnoho movlennia majbutnikh uchyteliv. Poliloh mov i kul'tur: osvitnij i kul'turolohichnyj aspekty. Materialy Vseukrains'koi naukovo-praktychnoi konferentsii molodykh naukovtsiv, 27 bereznia 2018 r. (ss. 48-50). Chernihiv: RVV ChNPU imeni T. H. Shevchenka.

Ukrajins'ka, O. (2009). Metodyka testuvannya rivnya sformovanosti movlenjevoji kompetentsiji majbutnikh vykladachiv u govorinni frantsuz'koyu movoyu. (Kandydats'ka dysertatsiia). Kyivs'kyj natsional'nyj linhvistychnyj universytet, Kyiv, Ukraina.

Chernysh, V. (2015). Teoretyko-metodychni zasady formuvannya u majbutnikh vchyteliv profesijnoorijentovanoji anglomovnoji kompetentsiji v govorinni. (Doktors'ka dysertatsiia). Kyivs'kyj natsional'nyj linhvistychnyj universytet, Kyiv, Ukraina.

Shatylov, S. F. (1986). Metodyka obuchenyya nemetskomu yazyku v srednej shkole. Moskva: Prosveshchenye. 